\title{
RELIGIOUS BLASPHEMY AND MONITORY SOCIETY IN INDONESIAN DIGITAL AGE
}

\author{
*Leonard Chrysostomos Epafras, Hendrikus Paulus Kaunang, and Syamsul Asri \\ Inter-religious Studies (IRS) Program \\ The Graduate School of UGM
}

Submitted:21-11-2018; Revised: 25-04-2019; Accepted: 25-04-2019

\begin{abstract}
ABSTRAK
Artikel ini adalah laporan penelitian atas wacana penodaan agama dalam kaitannya dengan praktek digital di Indonesia. Artikel ini berusaha memahami pergeseran partisipasi publik dalam membentuk wacana tersebut, yang kesemuanya dibingkai dalam kondisi yang kami sebut "masyarakat monitor." Penelitian ini adalah penelitian kualitatif dengan beragam metode termasuk wawancara dan pengamatan di media sosial. Wacana penodaan agama sudah tua usianya tetapi di era digital ini muncul dalam wajah yang rumit karena digerakkan dalam logika informasi digital yang menekankan pada aksesibilitas, efisiensi pesan, dan unjuk kerja. Berdasarkan amatan perkembangan politik saat ini, tampaknya wacana penodaan agama terserap dalam wacana politik dalam rupa informasi yang digunakan sebagai bagian dari pertarungan politik (weaponized information). Dalam kondisi ini bisa jadi wacana ini menyendatkan proses demokrasi digital, yang dahulu sempat menjadi retorika kemunculan teknologi digital. Pada akhirnya, wacana ini lebih berbicara soal kesalehan publik dan ketertiban umum. Ia lebih mengutamakan batas-batas yang dapat diterima dalam wacana agama daripada berbicara soal peningkatan kehidupan beragama dan kesalehan pribadi.
\end{abstract}

Kata Kunci: Demokrasi digital; Masyarakat monitor; Penodaan agama.

\begin{abstract}
The present article is a research report on the discourse of religious blasphemy in connection with digital practices in Indonesia. It sought to understand the shift of public participation in shaping the discourse that understood within the framework we identified as "monitory society." The research employed qualitative approach by using several methods, among others are interview and social media observation. Reflecting upon the current national trends and new shift of political landscape, it appeared that religious blasphemy immersed into the political discourse as weaponized information, hence disrupted the meaning of democracy in digital age, as once become the rhetoric of digital technology. In general, the discourse of religious blasphemy in Indonesia is dealing with public piety and social order. It concerned more on religious boundary rather than the improvement of religious lives and personal piety.
\end{abstract}

Keywords: Digital democracy; Monitory society; Religious blasphemy

*Corresponding author: leonard.epafras@mail.ugm.ac.id.

Copyright@ 2019 THE AUTHOR(S). This article is distributed under a Creative Commons Attribution-Share Alike 4.0 International license. Jurnal Kawistara is published by the Graduate School of Universitas Gadjah Mada. 


\section{INTRODUCTION}

The rapid sociopolitical changes in contemporary Indonesia could be understood as expanding and extension, and also shifting position of the guardian of democracy. Besides the presumed three traditional estates of democracy, viz. The legislature, executive, and judiciary institutions, many argued that journalism and the press occupied the fourth estate to provide a checking point of the governance machinery (See Powe, 1992; Baker, 2006). Journalism exercised its communicative function as conduit amongst the state, market and the citizen. Particularly in relationship with the state, press in different quality and degree performed the function of "monitory." As observed by John Keane, lately there was emerged another monitorial estate - arguably a "fifth" estate - i.e. watchdog organizations that summoned the state in regards of the quality of public policy produced by the government (see Keane, 2010). In Indonesian context we witnessed the emergence of such institutions such as Indonesian Forum for the Environment (WALHI/ Wahana Lingkungan Hidup Indonesia), Indonesian Corruption Watch (ICW), Alliances for Customary Society (AMAN/Aliansi Masyarakat Adat Nusantara). They played crucial role in shaping and reshaping the democratic quality. The emergence of internet further reconfigures the meaning of this monitorial democracy as there is a growing unprecedented participation of the public, which once it gave a promise for democratization of public space.

To the latter and in Indonesian context, a note necessary to put forward as a crucial moment took place in 2010, when the global capital repatriation flowed into the Indonesian market, in response to the United States and European economic crisis. Indonesia received significant global capital injection that in a way stimulated the government and commercial sector to provide better internet infrastructure. Despite the euphoria of the freedom of information access, it brought the amalgam of dividends but also constraints, as many of Indonesians then were less prepared for digital life and its complexity.

In terms of democratic institution and its quality, what come next is predictable; the Web 2.0 e-ruption, notably driven by social media services (Fraser and Dutta, 2008, p. 144) shaped in part of the Indonesian democracy space, as it dispersed the centers from the former institutional orientation to multiple political practices, including those shaped by new actors and other subjectivities. To this condition we may notice the monitory function further expanded from press and watchdog organizations to the larger citizen complicity.

This shift must not be understood as the triumph of digital democracy over offline democracy, but rather a crucial dialectic among the estates whose determined the quality of democracy. In this dialectic, the monitory function of press and watchdog organizations is pushed forward by ordinary individual citizen, in extended and multiplied way made possible by internet. Any societal element now has the capacity and technology not only to obtain information, establish digital social life, but also on the other hand, to observe and monitor other activities that affected to their "ideological" and rightsizing their "political" persuasion, which at some point trigger a collective activity among the people shared the same position. More than just internet, it was also because of the implementation of the communication regulation, viz. Law No. 11/2008 on Information and Electronic Transaction (revised by Law No. 19/2016, altogether hereinafter "UU ITE"), which provided a new social space for the public at large to exercise their rights within the context of digital activities. At this juncture the caveat of UU ITE and democracy in digital era, in relationship with the discourse of religious blasphemy is lurking.

In this article, we looked on the increasing public participation to made use democratic arms, in particular law enforcement agencies and justice system, to extend their concerns, which in some ways do not reflect the deliberation of democratic ends. Combined with the problem of corruption, in- 
competence, and complicated understanding of inter-religious relationship in Indonesia, the discourse of religious blasphemy at this point, is part of this equation.

Not with standing the long history of harmonious inter-religious interaction in Indonesia, it was also history of the uneasy relationship, notably between Muslims and the Christians. Within the frame of traumatic religious interaction (see Husein, 2005; Mujiburrahman, 2006), Indonesian political landscape shaped by its current practices related to the using of religious blasphemy as a weaponized information by the citizen. Internet and social media give a sense of collective panoptical power to observe, monitor, and response, even to the degree of invading other people private space. We understand this condition as "monitory society." The employment of UU ITE and law enforcement activities in relation to it gives a further gravity to complicated condition of democracy in digital age. We somehow entertained ourselves that at this juncture there is "democracy but without the democrats."

In the present-day world, there is an indication of the raising disaffection among the public toward democracy. The election of some "right-wing" global leaderships such as Donald Trump, Rodrigo Duterte, and Narendra Modi in the political stages might give some justification to this trend.

The problem even more suppressing with the stronger implementation of law against religious blasphemy in many countries in the world, including those that adopted "democratic" systems. Pew Research Center registered 32 countries that maintained religious blasphemy law (Grim, 2012). On the other hand, the Brookings Institution furthermore reported that " $47 \%$ countries and territories in the world applied different degrees of laws against religious blasphemy." As pointed out by an Indonesian journalist, the law is not necessary protecting the sacred of religion, it is become a stick to suppress the minority groups, such as Ahmadiyya and Shi'ite in Indonesian case (Bayuni, 2011). Accordingly, the law against religious blasphemy "forbid insulting religion and religious symbols or interpreting religious texts in a way that conflicts with the state's interpretation" (Fiss, 2016, p. 5).

For some outsiders, Indonesia is portrayed as an example of successful country managing religious diversity. They championed Indonesia for not falling into religious-based state, though hosting the largest Muslims in the world. However, there were complicated historical precedence that Indonesia never a straight forward exemplary country. The picture is much more complicated, the challenge is great, and different streams of socio-political and religious processes were overlapping. Many of the scholars believed that the "conservative turn" was on the rise (Bruinessen, 2013), while other identify the "pastoral turn" in which the governmentality over the public piety endorsed by multiple levels of society (Epafras, 2019). Some other more optimistic and balanced, since they believe that there is remain a strong civil society in Indonesia (Seo, 2013; Zuidweg, 2018).

The complexity even greater after the cease of Soeharto's administration and Indonesia entered to what was called Reformation Era in 1998. One of the features of this era is the "return of the suppressed." The effects of this was immensed. People testified the increasing of politics of identity and transnational religious discourse.

On the flipside, at this historical moment there was the first step toward digital society and the creation of Indonesian netizens. However, regardless the initial dream of the greater penetration of democracy in the public lives, apparently the digital exposure does not necessarily correlate with the development of democracy in certain country (Kluver and Banerjee, 2005). On the other hand, digital technology induced a unique social behavior including those of religious behavior and fueled the more confrontational politics of identity and compartmentalized religious expression.

Another interesting development is that the raising of what earlier John Keane intro- 
duction of "monitory democracy" (Keane, 2010; 2011; 2013). As earlier mentioned, it could consider as the fifth pillar of democracy, in which there emerged the civil society organizations that the sole purpose is to control and check the government on the matter of public goods and policies. In this research, we push little bit this issue in regards of religious discourse that in the context of monitory democracy, the bargaining position of certain religious authority, such as Indonesian Ulema Council (MUI), partisan and nonpartisan groups are also increasing. They are more than just tending the spirituality and protecting religious precepts in public space, arguably such institution also shaped the government policy, through summoning to it in regard of religious matters - thus may also shape the democratic process - through their position as "representation" of the entire religious community.

Inspired by the notion of "monitory democracy" we establish the notion "monitory society," in order to understand the activities of netizens who intentionally or unintentionally responses to certain religious subject which considered important for their religious security. This action presumably derived from the digital social practice that open up public (netizens) participation in shaping certain discourse in costless manner.

If this notion is justified then we will take this as the pre-condition for our research project that specifically focusing on religious blasphemy, in which through the discourse of monitory society the subject is no more confined in the legal system and religious precept, but it may extend into a species of governmentality (Foucault, 1991). Furthermore, through the investigation of the above subject, the research will relate it to the formation of digital democracy.

Since the promulgation of the anti-blasphemy law - officially Presidential Decree No.1/1965 (in 1969 it ratified into a Law No. 1/PNPS/1965) on the Prevention of the Religious Abuse and/or Blasphemy (hereinafter PNPS 1/1965) - and coupled with the Criminal Code Article 156a up until 2017, there were 60 cases of Religious Blasphemy, or roughly two cases per year (Hukumonline. com, 2017). Other even claimed that since the inception of the law, there was 97 cases of religious blasphemy (Wardah, 2017). Many of the cases are cause célèbre, such as H.B. Jassin and Arswendo Atmowiloto (before UU ITE), and Alexander Aan, Ahok, Ade Armando, Sukmawati Soekarnoputri, Meiliana, and Abraham Moses (after the implementation of UU ITE). It is interesting to aware of that during the dictatorship of New Order (1968-1998), there was only eight cases of religious blasphemy, the rest are produced after Reformation era (Wardah, 2017; Hefner, 2018, pp. 15-16). When this paper is finalized there was a new case of religious blasphemy indicted against two stand-up comedians, Tretan Muslim and Coki Pardede, incited by a popular ustadz, Derry Sulaiman (Rismoyo, 2018). This latest case just gives another boost for the condition of "monitory society."

Based on discussion above, we try to formulate our research questions: How the recent digital practice surrounding the discourse of religious blasphemy understood within the "monitory society"? Indonesian democracy in this regard is considered as the framework of modern Indonesian socio-political activities, in which all implied political actors, including the anti-democratic actors were presumed as the active agents for the formation, cancellation, and modification of democracy. Hence the final question is how religious blasphemy shaped the digital democracy?

The present research project is based on the observation upon the meso-processing of the issue at hand. Focus on the meso-processing allowed us to see the larger pattern and general practice (macro-processing) only in limited and selected way. Even though could not take a deeper and continuous observation either, as expected in the micro-processing, such as taken by ethnography approach, it allowed us to found interesting detail through interview and close observation toward the social media. 
Data collection initially projected to a broad spectrum of resources, including the religious authorities, law enforcement elements, such as Cyber Crime unit of the Police Force and State Attorney. However, we encountered some setback during the field research that hindered us to include those elements.

The research methods employed several techniques, viz. literature survey, digital data collection, interview, and focus group discussions (FGD). For the digital data collection, we use Facebook accounts, Twitter accounts, news outlets as the core data source by activating 21 keywords, such as "religious blasphemy" Thus far, we collected roughly 400 articles.

Altogether we interviewed ten sources and organizing two Focus Group Discussions. The participants were including lecturers, social media activists and authority and law enforcement elements. Lastly, we observed in general the social media and internet sporadically, mainly from the media online outlets.

\section{Theoretical Framework}

There are several works that preceded the present undertaking and though are not identical in concern and scope, those became the backdrop for it. To name the few, the edited volume by Tim Lindsay and Helen Pausacker, Religion, Law and Intolerance in Indonesia (Lindsey and Pausacker, 2016) dealing with the relationship between law and intolerance in Indonesia. Within this volume the work of Nadirsyah Hosen on the 2012 Jakarta Gubernatorial Election became a premium example in understanding the background for Ahok's case in 2017 (Hosen, 2016). The article from Ismail Hasani on Alexander Aan, the Atheist Minang would be among the first examples of the implementation of UU ITE upon religious blasphemy case (Hasani, 2016). The newly issued edited volume entitled Digital Indonesia: Connectivity and Divergent, edited by Edwin Jurriëns and Ross Tapsell (Jurriëns and Tapsell, 2017) though not specifically dealing with religious blasphemy, provided rich understanding of the recent development of Indonesian digital realm, including some issues touched upon the formation of digital democracy and cybersecurity (Raharjo, 2017). John Postill and Leonard Epafras producing the analysis on the complexity of Indonesian hybrid media space with an example about the charge of religious blasphemy to Ahok. In the article they argued among other that Indonesia hybrid media space could became the space for intensifying and recasting the old issues such as Christianization and the peril of Indonesian Chinese (Postill and Epafras, 2018).

What would be the contribution of the present undertaking? Taking this subject within the religious studies, will give a perspective through which the notions of "religion" and "religiosity" are problematized. Those are located in the classical tension between structure and subjectivity - or agency. The charge of religious blasphemy for instance, will not be seen as part of the process of governance, by the powerful actors such as police force or Indonesian Ulema Council (MUI), but as also a governmentality (Foucault, 1991), in which "conduct of conducts" as the representation of power-qua-relationship is endorsed by different level of societal agencies, and all of those willingly or unwillingly let themselves being disciplined. On the other hand, this can also be seen as multiple understanding of religion endorsed from different subjectivities - in itself is a presentation of "vernacular religiosity," religious expressions of ordinary people (Ammerman, 2007 , p. 5). Hence, the implementation of UU ITE to the religious expression might be seen as the interlocking of different subjectivities and interpretation of religions, taking place in between the "structure" and the various "subjectivities."

It is important to understand that the digital platform as an instrumentalized, highly mediated, and algorithmized platform in which drives the information efficiency that "conflates rational discourse with an instrumental rationalization" (Nunes, 2012, p. 163). Over this platform we might be encoun- 
tered with the condition of "epistemic bubble" and "echo-chamber rationalization" that rampant in the competing information exchange (Nguyen, 2018). The effect of this condition is hoaxtivism, i.e. a production, consumption and distribution of "hoax" as a social practice (Epafras, Djalong, and Kaunang, 2018).

One last note, a number of studies emphasis the shift of authority over the highly mediated system. The reporting of religious blasphemy mostly conducted by non-religious authority actors, hence teasing us to think more on subjectivity in the digital realm. Deleuze and Guattari proposed the notion of rhizome in understanding networking model of relationship, against the hierarchical. One condition of this rhizome is the disconnected becoming (Deleuze and Guattari, 1987, p. 11) of a subjectivity on digital platform, that is not necessarily a "disconnection" from the existing and traditional hierarchical system, but in many ways is a new initiative to forge link and subscription to different authorities, hence creating a heterarchical connectivity (Crumley, 1995; Epafras, 2016, p. 7). Taking this together, we may encounter complicated arrangement of religious authority and the formation of digital democracy.

\section{DISCUSSION}

Historically, many of the world religions created the boundary encircled what is presumed as the sanctity of religious precepts by developed the logic of Othering. The Roman/ Latin Catholic church established the Curia Romana and Inquisition Court in order to secure the Church's teaching from defamation and blasphemy (Lynn, 2015). The Protestant Reformators, notably Martin Luther and John Calvin were also maintained harsh measures against Protestant's dissidents (Levy, 1998, p. $569,2005)$.

Those boundaries making was getting even more gravity in the digital age. Earlier research on hoaxtivism, the team found that beside the dividends brought the digital communication; it also brought ambiguity such as the creation of an epistemic bubble for people that limit their interest to meet face-to-face with other parties. This is only emphasis the problem of the validity of the information traffic among the parties as well, unless they invest sufficient time to filter and clarify the information. Furthermore, the technology is affirming the condition of individualization of modern age in which it turned a social self into "a reflexive self," which is in daily practice appeared in the digital narcissism and clicktivism. This in turn might be severed the existing social cohesion. From the perspective of law enforcer, in this case attorney, the condition is confirmed through the increasing number of cases of the defamation, religious blasphemy, online scam, hoax, and black campaign charges by way of UU ITE.

The proposed notion of "monitory society," i.e. "public participation on monitoring social lives, in which the objective is not necessarily in line with democratic ideals such as a better public policy, but a reflection of parochial ends," might be also an extension of Foucauldian "governmentality," a life governance conducted by different element of society in the maintaining certain version of social lives. On the level of social practice, this condition amplified by social media, which gave a strong incentive for people to penetrate other people lives - kepoism in Indonesian popular expression - to take interest of other people doing and activities. This is indeed increasing the public participation as well in socio-political lives including the in the political lives such as the presidential and gubernatorial elections. "Arab Springs" gave an ample image on how the digital communication truly makes a significant change in a political landscape. Nonetheless, as the case of Jakarta gubernatorial election taught us, it also marking the fundamental shift of people interaction, to the point many people lamented for the loss of tabayyun and silahturahmi ethos, and other lamented for the coming of the "Post-Truth" society. All in all, it may emphasis the condition of the fourth phase of internet control, observed by Deibert (2012), the phase of "the access contested" in which indicated by competition of accessibility and control, not only by the government, but also 
by the corporates, and the public at large. Many cases of religious blasphemy, such as Arswendo Atmowiloto, Alexander Aan, Ahok, Ade Armando, and the last one, Ustad Evie Effendi, were endorsed and incited by non-governmental, non-official actors such as Jonru and IPNU (Ikatan Pelajar Nahdlatul Ulama - Nahdlatul Ulama Student Association).

The public practice of reporting certain cases through the various digital outlets were in itself could be seen as the improvement of public participation in the law enforcement, in particular in shaping the digital society. However, the enthusiasm for charging other people through these venues in part reflected the aforementioned reflexive condition rather than, as an informer lamented, projecting the legal ideal, in particular in Indonesian context, i.e. the criminal charge is the last option after the other socio-cultural options are exhausted.

The condition of "monitory society" in regards of religious blasphemy case might be best illustrated by the cause celebre, such as the 2017 Jakarta's gubernatorial race, which implicated to one of the candidates, Basuki Purnama Tjahja, renowned as Ahok. There were 14 reportings on Ahok's alleged act of religious blasphemy submitted to five regional police departments. Most of reporters were civilians and/or civil society organizations.

To understand further the above complicated condition of "monitory society", in the following some observation from the field research might give a better sense of the above condition. The shortlist is included an attorney, government officials, MUI representation, a newspaper representation, case in Bali Island and in Manado.

The first informer, an attorney in an interview assessed, in a nostalgic tone that before the expose of digital technology, there were musyawarah (discussion), tabayyun (act of clarification), and other intimate and faceto-face communication that prevailed over the criminal indictment. The present day marked with the hyper-sensitive interaction that forced the attorney to deal with trivial issues over minor differences among the people. Personally, he tended to recommend to the parties in dispute to take the "familial" approach (penyelesaian secara kekeluargaan), over legal measure. He envisioned that UU ITE is not a judgemental instrument, as it provides security and safety in using digital communication. In general, this principle for him, is the fulfilment of the restorative justice.

The government position, in this case the Ministry of Communication and Information (Kementerian Komunikasi dan Informasi-hereinafter Kemenkominfo) on the issue of religious lives and in particular on the religious blasphemy is expected to maintain the stability and the status quo. As the guardian of the establishment of the digital society, Kemenkominfo does not defining the legal and religious aspect of the digital interaction, such as in the case of hoax, LGBT and religious blasphemy. It depended entirely on the Ministry of Religious Affairs and the Law Enforcement's understanding on the respected issues. However, the Ministry actively endorsed the existing religious institutions to provide guidance on the "responsible internetting and social media practice." It helped to produced the Muamallah Medsos, "Dealing with Social Media" by Indonesian Ulama Council (MUI/Majelis Ulama Indonesia (2017)), Warga Gereja Gereja Merespon Revolusi Media Sosial: Panduan Bermedia Sosial, "The Church Members Responded the Social Media Revolution: A Guidance for Social Media Activities" by Indonesian Fellowship of Churches (PGI/Persekutuan Gereja-Gereja Indonesia) (PGI, 2018), and Pedoman Penggunaan Media Sosial, "The Guidance for Social Media Usage" by the Bishop's Conference of Indonesian (KWI/Konferensi Waligereja Indonesia) (Nugroho and Oetomo, 2018).

UU ITE, endorsed by Kemenkominfo, is the only legal safeguarding for internet and social media activity. However, when confronted with the reality of "very flexible" implementation of the law, which claimed many "ordinary people" in order to save "the 
powerful," the government official pointed out the importance of government regulation to control the overspilling effect of the internet. There is "no absolute freedom of speech" ("Tidak mutlak kebebasannya untuk berbicara atau beropini").

Another government official pointed out that the discourse of "religious blasphemy" strongly related to the Islamic position in maintaining the purity of religious precept, rather than a generic discourse of all religions in Indonesia. He also emphasized the elastic understanding of "religious blasphemy" offered by the religious authority, such as in the case of Arswendo Atmowiloto, renowned as "Monitor case" (1990) and Tajul Muluk case in Sampang (2012). The boundary was so broad that it gave a space for insertion of the political agenda into the case.

In connection with the government policy, he further lamented that the legislation process of religious issue conducted by the lawmakers "in Senayan" - the seat of the House of Representation - were lack of religious insights upon the issues and instead of resolution the problem they created fragmentation and discrepancy on the policy implementation, including between the central and regional governments.

At the level of non-governmental religious institution, MUI became a case in hand in understanding the intricacy of the societal element of monitory society. MUI is a reflection of monitory democracy, as it played in two fronts, as a "player" at the front stage and "neutral judge" in the backstage. At the front stage it actively monitoring the Islamic matters circulated in the Muslim and the larger public space. Since the Reformation, notably during the administration of Susilo Bambang Yudoyono (renowned as SBY), was given more muscle and its status was no more symbolic as in the past. The council became an active player in defending Muslim affairs and interests, even at the level of disciplining any other religious groups, mostly within Islam, which was considered displaying a dissidence tendency. On the backstage, MUI actives in judicial process, notably if the case of what considered as religious blasphemy emerged, by positioning as expert consultant and religious authority referred by the law enforcements. Both positions reached through two different measures, i.e. persuasive and combative.

Unique position held by Republika, the largest Muslim newspaper in the country. It become an active monitory subject just like any other press, Republika hold the view that in general Indonesian Muslims stucked in the "procedural democracy" after a huge euphoria immediately after the downfall of Soeharto. The quality of Indonesian democracy is stagnant and it never benefitting Muslim constituents in substantive way. Therefore, Republika channeling the Indonesian Muslim grieve in pushing the democratic corridor toward the larger Muslim's public space.

From the perspective of human rights enforcement, religious blasphemy is only a subset of the larger discussion of the freedom of religious expression. And the picture is bleak as the mounted victims of the Blasphemy Law. An official from The National Commission on Human Rights (Komisi Nasional Hak Asasi Manusia - Komnasham) made a critical assessment toward the Blasphemy Law (PNPS 1/1965). Indonesia, he alluded that what is needed in Indonesia is not such blasphemy law, but a law who managed the religious lives and interaction among religious communities.

In the case of Bali Hinduism, the challenge of religious lives is somewhat related to the tension among the Balinese Hindus and transnational Hindu religious expression, such as Sai Baba movement, Balinese Hindus and the cosmopolitan representations through tourism industry, and the migrants, including the Javanese migrants. Hence, the complicated inter-religious interaction among other framed within the raising ethno-nationalism among some Balinese, revolved around the figure such as Arya Wedakarna, "the intolerance Hindu" (see Muhajir, Artawan and Adnyana, 2013).

Finally, the religious blasphemy case recalled the organization of the Interfaith 
New Generation Initiative and Engagement (INGAGE) program, in Manado, North Sulawesi. The case was trigerred when some of the participants shared the enthusiasm and interfaith experiences in the social media. While many of the activities were replicating the regular interfaith activities such as visiting house of worships, others - in fact, non-programmatic - were included the participation in the Friday's prayer service. To the latter was the incitement of many North Sulawesi's Muslim community was directed, which including the charge of religious blasphemy as it was presumed as the trespassing of religious boundary. Huge efforts were conducted to limit the aftereffect, including a series of cordial visits to the government and religious institutions to explain the situation on the ground.

\section{CONCLUSION}

In general, the discourse of religious blasphemy in Indonesia is dealing with public piety and social order. It concerned more on religious boundary rather than the improvement of religious lives and personal piety. Digital technology that flourished after the fall of New Order just gives a larger incentive for the spreadout of religious blasphemy as the implication of the digital logic of which emphasize access, efficiency and maximum performance of the message circulated.

Within the digital context, the discourse has to be understood within at least two conditions. Firstly, the logic of virality, collective action, and larger public participation became almost a "rule of thumb," as earlier claimed the condition of "monitory society." Secondly, there is no dichotomy between "truth" and "falsehood," "religionist" and "trickster," as all of them are inhabit the same instrumentalized platform. This might be the condition lamented by many as a condition of "post-truth society," in which people do not interested in hard fact but aligned themselves to the ideological, taste, emotional and political leaning. At this juncture, the politics of Othering found its home, often framed within the discourse of religious blasphemy.

\section{ACKNOWLEDGEMENT}

Initial idea entitled "Religion and Digital Democracy" was presented in the $10^{\text {th }}$ IGSSCI Conference on 30-31 October 2018. The project is funded by the Inter-Religious Studies Program, The Graduate School of UGM.

\section{BIBLIOGRAPHY}

Ammerman, N. T. (ed.) 2007. Everyday religion: observing modern religious lives. Oxford: Oxford University Press.

Baker, C. E. 2006. Media Concentration and Democracy: Why Ownership Matters. Cambridge: Cambridge University Press.

Bayuni, E. 2011. Bloody Blasphemy: Antagonizing Religious Minorities in Indonesia and Pakistan, Asia Pacific Bulletin, 97. Available at: https://scholarspace.manoa.hawaii.edu/ bitstream/10125/19843/1/apb097_5.pdf.

Crumley, C. L. 1995. Heterarchy and the analysis of complex societies, Archeological Papers of the American Anthropological Association, 6: 1-5.

Deibert, R. J. et al. (eds) 2012. Access contested: security, identity, and resistance in Asian cyberspace information revolution and global politics. Cambridge: MIT Press.

Deleuze, G. and Guattari, P.-F. 1987. A Thousand Plateaus: Capitalism and Schizophrenia. Translated by B. Massumi. Minneapolis: University of Minnesota Press.

Epafras, L. C. 2016. "Religious e-Xpression among the Youths in the Indonesian Cyberspace", Jurnal Ilmu Komunikasi, 13(1): 1-18.

Epafras, L. C. 2019. “‘Imagined Immunities:' Religion, Governmentality and Civility in Indonesian Cyberspace", in Sofjan, D. (ed.). Religion in Public 
Sphere. Forthcoming. Geneva: Globethics.net.

Epafras, L. C., Djalong, F. A. and Kaunang, H. P. (2018). "Beyond Signal and Noise: Academics goes Hoax and Hoaxtivism", Kawistara, 8(3): 347261.

Fiss, J. (2016). Anti-blasphemy offensives in the digital age: When hardliners take over. Washington D.C.: The Brookings Institution.

Foucault, M. (1991). The Foucault effect: studies in governmentality with two lectures by and an interview with Michel Foucault. Edited by G. Burchell, C. Gordon, and P. Miller. Chicago: University of Chicago Press.

Fraser, M. and Dutta, S. (2008). Throwing sheep in the boardroom: how online social networking will transform your life, work and world. Hoboken: Wiley.

Grim, B.J.(2012). “LawsPenalizingBlasphemy, Apostasy and Defamation of Religion are Widespread." Pew Research Center. Accessed: 22 August 2018. Available at: http://www. pewforum.org/2012/11/21/lawspenalizing-blasphemy-apostasyand-defamation-of-religion-arewidespread/.

Hasani, I. (2016). “The Decreasing Space for Non-Religious Expression in Indonesia: The Case of Atheism", in Lindsey, T. and Pausacker, $\mathrm{H}$. (eds) Religion, Law and Intolerance in Indonesia. Amazon Kindle. London: Routledge, pp. 197-210.

Hefner, R. W. (2018). "Indonesia at the crossroads: imbroglios of religion, state, and society in an Asian Muslim nation", in Hefner, R. W. (ed.). Routledge handbook of contemporary Indonesia. London: Routledge, pp. 3-30.

Hosen, N. (2016). "Race and Religion in the 2012 Jakarta Gubernatorial Election", in Lindsey, T. and Pausacker, $\mathrm{H}$. (eds) Religion, Law and Intolerance in Indonesia. Amazon Kindle. London: Routledge, pp. 180-194.

Hukumonline.com (2017). “Vonis Kasus Penodaan Agama Rata-Rata 2 Tahun", hukumonline.com. Accessed: 27 May 2018. Available at: http:// www.hukumonline.com/berita/ baca/1t58a2c0a8bc3ac/vonis-kasuspenodaan-agama-rata-rata-2-tahun.

Husein, F. (2005). Muslim-Christian relations in the New Order Indonesia: the exclusivist and inclusivist Muslims' perspectives. Bandung: Mizan.

Jurriëns, E. and Tapsell, R. (eds) (2017). Digital Indonesia: connectivity and divergence. Singapore: ISEAS - Yusof Ishak Institute.

Keane, J. (2010). The Life and Death of Democracy. Reprint edition. London: Simon \& Schuster.

Keane, J. (2011). "Monitory Democracy?", in Alonso, S., Keane, J., and Merkel, W. (eds). The Future of Representative Democracy. Cambridge: Cambridge University Press, pp. 212-235.

Keane, J. (2013). Democracy and media decadence. Cambridge: Cambridge University Press.

Kluver, R. and Banerjee, I. (2005). "Political Culture, Regulation, and Democratization: The Internet in nine Asian nations", Information, Communication and Society, 8(1): 3046.

Levy, L. W. (1998). Blasphemy: Verbal Offense Against the Sacred, from Moses to Salman Rushdie. Chapel Hill: The University of North Carolina Press.

Levy, L. W. (2005). “Blasphemy: Christian Concept", Encyclopedia of Religion. 2nd ed. Edited by L. Jones. Detroit: Macmillan Reference USA.

Lindsey, T. and Pausacker, H. (eds). (2016). Religion, Law and Intolerance in 
Indonesia. Amazon Kindle. London: Routledge.

Lynn, K. 2015. Between court and confessional: the politics of Spanish inquisitors. Cambridge: Cambridge University Press.

Majelis Ulama Indonesia 2017. Fatwa Majelis Ulama Indonesia Nomor 24 Tahun 2017 tentang Hukum dan Pedoman Bermuamalah Melalui Media Sosial. Jakarta: Majelis Ulama Indonesia.

Muhajir, A., Artawan, E. J. and Adnyana, P. (2013, 27 January). "Kontroversi Pengaku Raja Majapahit Bali", Balipublika.

Mujiburrahman 2006. Feeling Threatened: Muslim-Christians in Indonesia's New Order. PhD Dissertation. Utrecht: ISIM.

Nguyen, C. T. 2018. “Why it's as hard to escape an echo chamber as it is to flee a cult", Accessed: 9 April 2018. Aeon. Available at: https://aeon.co/ essays / why-its-as-hard-to-escapean-echo-chamber-as-it-is-to-flee-acult.

Nugroho, A. and Oetomo, B. S. D. (eds). 2018. Pedoman Penggunaan Media Sosial. Jakarta: Tim Komisi KOMSOS KWI.

Nunes, M. 2012. "Abusing the Media Viral Validity in a Republic of Spam", in Gournelos, T. and Gunkel, D. J. (eds). Transgression 2.0: media, culture, and the politics of a digital age. Amazon Kindle. New York: Continuum, pp. 154-168.

PGI 2018. Warga Gereja Merespon Revolusi Media Sosial: Panduan Bermedia Sosial.
Jakarta: Persekutuan Gereja-gereja di Indonesia.

Postill, J. and Epafras, L. C. 2018. “Indonesian Religion as a Hybrid Media Space: Social Dramas in a Contested Realm", Asiascape: Digital Asia, 5(1): 100-123.

Powe, L. A. 1992. The fourth estate and the Constitution: freedom of the press in America. Berkeley: University of California Press.

Raharjo, B. 2017. "The State of Cybersecurity in Indonesia", in Jurriëns, E. and Tapsell, R. (eds). Digital Indonesia: connectivity and divergence. Singapore: ISEAS - Yusof Ishak Institute, pp. 110-123.

Rismoyo, M. 2018. “Dituding Nistakan Agama, IG Tretan Muslim-Coki Pardede Digeruduk Netizen", detikHot. Accessed: 21 October 2018. Available at: https:/hot.detik.com/ celeb/d-4265648/dituding-nistakanagama-ig-tretan-muslim-coki-pardededigeruduk-netizen.

Seo, M. 2013. State Management of Religion in Indonesia. London: Routledge.

Wardah, F. 2017. “Setara Institute: 97 Kasus Penistaan Agama Terjadi di Indonesia," VOA Indonesia. Accessed: 22 August 2018. Available at: https://www.voaindonesia.com/a/ setara-institute-terjadi-97-kasuspenistaan-agama-/3848448.html.

Zuidweg, N. 2018. "The Secularity Debate in Indonesia: Ahok's Blasphemy Case." Master Thesis. Utrecht: Utrecht University. 